Article

\title{
Corporate Philanthropy Affecting Consumer Patronage Behavior: The Effect of Reciprocity and the Moderating Roles of Vicarious Licensing and Strategic Fit
}

\author{
Erin Cho ${ }^{1}$, Jihyun Lee ${ }^{2, *}$ and Yuri Lee ${ }^{3}$ \\ 1 Strategic Design Management, School of Design Strategies, Parsons, New York, NY 10011, USA; \\ choje@newschool.edu \\ 2 Department of Fashion Marketing, Textile \& Fashion Campus of Korea Polytechnics, Daegu 41027, Korea \\ 3 Department of Textiles, Merchandising and Fashion Design/Research Institute of Human Ecology, \\ Seoul National University, Seoul 08826, Korea; yulee3@snu.ac.kr \\ * Correspondence: kj-pyo@hanmail.net; Tel.: +82-53-980-1262
}

Received: 18 April 2017; Accepted: 20 June 2017; Published: 23 June 2017

\begin{abstract}
This study investigates the manner in which corporate philanthropy affects consumer patronage toward a brand. In so doing, we propose reciprocity as a key mechanism, which manifests the effect of corporate philanthropy on patronage behavior, and examine how vicarious licensing and strategic fit would mitigate the relationship between reciprocity and patronage behavior. The results indicate that reciprocity significantly increases one's intention to participate in the philanthropic activities that a company supports and the intention to purchase its products. Vicarious licensing is found to lessen the effects of reciprocity on participation intention and purchasing intention. Strategic fit strengthens the path from participation intention to purchasing intention.
\end{abstract}

Keywords: philanthropic responsibility; reciprocity; licensing; strategic fit; participation intention; purchasing intention

\section{Introduction}

Corporate philanthropy $(\mathrm{CP})$ refers to the voluntary donation of tangible and/or intangible resources by a profit-seeking company to its local, national, or international communities to promote the welfare of others and to achieve a positive social impact [1,2]. Although gifts of cash are the most common forms of $\mathrm{CP}$, corporate giving can take many different forms, such as donating a company's products/services, employee time, and expertise, providing the use of a company's facilities and properties, and so on [3]. CP has increased steadily in the past 40 years, although it experienced a little retraction during the 2007-2009 recession periods. According to Giving USA, cash donations made by corporate America amounted to approximately $\$ 7.34$ billion in 1995, $\$ 15.50$ billion in 2005, and $\$ 18.45$ billion in 2015, with about a 4\% increase between 2014 and 2015 [4].

Broadly, CP has been considered one form of corporate social responsibility (CSR), which refers to a corporate self-regulatory mechanism to ensure and promote the common good and welfare of others $[5,6]$. CSR encompasses the notion that a firm should refrain from harming the environment and society in all processes involved in the production and distribution of their market offerings by which they profit (i.e., doing no harm), and that the firm should contribute to enhancing the welfare of society beyond generating positive externalities via their normal business activities (i.e., doing good). While the goals of "doing no harm" and "doing good" can manifest in many different facets of business operations, the following four dimensions are argued to constitute the key domains of CSR. They include: (1) an economic responsibility to be profitable; (2) a legal responsibility to obey all laws and 
regulations; (3) an ethical responsibility to adhere to the principles and ethical standards defined by stakeholders; and (4) philanthropic responsibilities to promote goodwill (for a detailed discussion, please see [1,7]). CSR activities to meet economic and legal responsibilities are "required", those for ethical responsibilities are "expected", and the philanthropic activities are discretionary, thus classified as "desired". As CSR activities move from required to desired, public criticism and legal enforcement weaken when a company does not meet them.

From a firm's strategic perspective, one critical debate concerning CSR has been whether engaging in CSR will generate meaningful returns, either in the form of avoiding penalties or improving a firm's competitive position, that are significant enough to justify the expenditure. While some studies have supported the role of CSR in benefiting a firm's financials as it improves brand loyalty [8], enhances reputations [9], and attracts investment [9], others have argued for the limited or even detrimental effects on the firm's bottom line when engaging in CSR $[10,11]$. For example, according to a survey conducted by GlobeScan and EAI in 2009, about $75 \%$ of respondents disagreed with the statement that "I buy products made by companies that practice CSR or recommend such companies' products to other people" [12]. The inconsistency found in the previous literature may have stemmed from the fact that the effects of CSR depend on several moderating factors, such as the perceived strategic fit between CSR and a firm's business model, the extent of consumer awareness and involvement, differing forms of CSR, the norms of a given industry, and so on (e.g., [7,13]). More studies are thus needed to provide a better understanding of the mechanism by which CSR influences consumer behavioral intentions. Our study addresses this issue in the context of corporate philanthropy (CP). By doing so, we aim to contribute to the current literature by providing a greater clarity in the following regards.

While CP has been discussed as a part of CSR, an argument has recently been made that CP should be treated as distinct from CSR [13-15]. Most notably, von Schnurbein et al. [15] contend that CSR and CP follow different conceptualizations, given that CSR is closely related to a firm's core business, thus being "considered a required and expected part of corporate product (p. 285)", while corporate philanthropy is strictly voluntary [16] and gears toward performing activities benefiting social communities outside the organization conducting CP. Furthermore, CSR is tightly linked to the concept of sustainability, and tends to be focus more on 'avoiding bad' not to be penalized [17], thus being more regulated by local, regional, and federal authorities than $\mathrm{CP}$ activities. Some scholars have also argued that a critical aspect of $\mathrm{CP}$ is a firm giving without the explicit pursuit of obtaining tangible gain for corporations [18]. This differentiates CP from corporate sponsorship, or cause-related marketing, which is a part of a firm's strategic marketing mix [18,19]. Husted and de Jesus Salazar [20] stressed the incompatibility in pursuing the maximization of both a firm's profit and social welfare simultaneously due to the inherent tradeoff between these two goals. Some, however, point out that while philanthropic activities, in principle, are a firm's discretionary and altruistic contribution to the social cause, they can be powerful ways to demonstrate a company's integrity and to communicate the values that the company stands for $[21,22]$. CP, thus, can be seen as donating corporate resources "to address nonbusiness community issues that also benefit the firm's strategic position and, ultimately, its bottom line" [22]. Yet, the extent to which CP is able to achieve this depends on how it is judged by consumers [23].

We follow the above conceptualization and investigate the strategic role of CP. In particular, we examine the way in which $\mathrm{CP}$ induces two different forms of a consumer's patronage behavior: (1) consumers' willingness to support a firm's philanthropic activities (i.e., participation intention); and (2) their willingness to purchase a firm's products or services (i.e., purchasing intention). We also identify critical perceptual factors that could strengthen or mitigate the effects of CP on these patronage intentions. In so doing, we propose that $\mathrm{CP}$ increases consumer patronage through the mechanism of reciprocity (i.e., feeling of obligation to respond to the positive action of an interacting party with another positive action) and examine how the perception of vicarious licensing (i.e., the extent to which consumers evaluate that the company contributed to society on their behalf) and strategic fit (i.e., the fit between the characteristics of the philanthropic activities and a firm's core expertise) 
moderate the impact of reciprocity on consumer patronage. The results of this study could not only enhance the theoretical understanding of the cognitive mechanism by which $\mathrm{CP}$ is evaluated, but also provide practical implications as to how a firm should structure its $\mathrm{CP}$ so as to enhance consumer involvement in its cause, which in turn leads to consumer patronage toward the firm.

\section{Literature Review}

In order to understand the $\mathrm{CP}$ affecting consumers' patronage behaviors, we employed social identity theory [24-28] as the conceptual framework. Social identity refers to "the individual's knowledge that he belongs to certain social groups together with some emotional and value significance to him of this group membership" [29]. People divide the world into "us" and "them" by putting people in different social groups, and then consider people in the same group similar to themselves and different from others outside the group (i.e., social categorization). Social identity is an individual's perception of who he or she is based on this group membership, which serves as the source of one's pride and self-esteem. It is important to note, however, that group membership may not always serve as a source of pride and self-esteem and that people can belong to a group that is socially stigmatized or occupies a low status within society $[28,30]$. To increase pride and self-esteem, particularly when it is difficult to abandon the group membership associated with socially undesirable qualities, people are often motivated to evaluate the situation and to behave in a way that enhances the images and status of the group to which they belong (i.e., in-group favoritism) [26,28,31]. Tajfel and Turner [32] further identified three key variables contributing to in-group favoritism. They included the extent to which (1) individuals identify with an in-group to internalize group membership as an aspect of their self-concept, (2) the prevailing context provides grounds for comparison between groups, and (3) individuals judge the perceived relevance of the comparison group. Turner and Tajel [33] and Hogg and Terry [34] further demonstrated that the mere act of individuals categorizing themselves as group members was sufficient to lead them to display in-group favoritism. This attitude change will in turn follow pro (or supporting) and counter (or rejecting) behaviors toward the group identity and/or activities [30,35].

In-group identification directing behavioral choices has been well supported in the context of CSR. Collier and Esteban [36], for example, reported that the degree to which employees can align their self-identity and image with the organization has a significant impact on employee motivation and commitment to CSR buy-in. In the context of consumer patronage behavior, in particular, Marin et al. [37] and Peloza and Shang [38] found that the influence of CSR on brand loyalty and purchasing intention hinges upon how significantly a consumer's social identity is aligned with a company's CSR initiative. In particular, the extent to which consumers perceive that their community is the recipient of the benefit (i.e., in-group identification) enhances their willingness to demonstrate patronage behavior toward the company, whose effect can be explained by the mechanism of reciprocity.

\subsection{Reciprocity}

Reciprocity refers to responding to the positive action of an interacting party with another positive action, since a favor from the other party produces a sense of obligation to return the favor $[39,40]$. Reciprocity results from one's evaluation that the other party performed an action with consequences that benefited the welfare of the person (or his/her community) and that the action was performed with good intentions [41]. Reciprocity is often regarded as a social norm governing the behavior of social actors-establishing that the right thing to do is to return the favor to those who helped you and those whom you help are obligated to repay. Marcel Mauss' early essay (1950) on the threefold nature of the gift-giving cycle (i.e., give-get-repay) helps explain why reciprocal obligations can be a powerful social force $[40,41]$. The obligation to give tends to be driven by the motivation to establish or maintain desirable relationships. However, receiving gifts could create tension due to an implicit recognition of dependence on the gift-giver. The motivation to reduce this tension forces a receiver to 
reciprocate what was given. Furthermore, the recipient's obligation to repay the gift received tends to depend upon the value of benefits received and the intensity of the recipient's need at the time when the benefit was provided [42]. However, even without substantial or proven outcomes, reciprocity may nevertheless be perceived simply by knowing that the companies are trying to perform beneficial acts for them or for the community to which they belong [43].

While the role of reciprocity has mostly been examined in the context of interpersonal relationships, evidence exists in consumer-to-business relationships indicating that consumer reciprocity generates significant endorsement behavior toward a company. Palmatier et al. [44], for example, showed that a firm's investments in customer relationship marketing evoked feelings of gratitude, which then led to gratitude-based reciprocal behaviors. Reciprocity also increases consumer trust toward a company, which in turn affects consumers' commitment and purchase intentions. In fact, feelings of reciprocity are known to be important in determining consumers' behavioral decisions toward a non-profit organization, such that reciprocity motivates consumers to participate in community activities and make charitable contributions to the cause that the firm supports $[45,46]$.

We thus expect that reciprocity will result in two different endorsement behaviors in our context: participation intention and purchasing intention. Participation intention refers to voluntary and active consumer participation in philanthropic activities that a firm organizes, and/or cooperation with the firm's employees in ways that promote the social causes that the firm supports $[47,48]$. Purchasing intention, on the other hand, is a consumer's willingness to purchase a product or service of the firm that engages in corporate philanthropic activities. We posit that the extent to which consumers perceive that their community is the recipient of a firm's philanthropic activities would have direct and positive effects on (1) a consumer's participation intention and (2) his/her purchasing intention.

We also expect that a consumer's willingness to participate in a firm's philanthropic activities will increase his/her purchasing intention of a product or service that the firm offers. A consumer's participation intention will further enhance his/her in-group identification, which will increase the endorsement behavior toward the firm they see as an in-group member. While not many studies have examined this relationship, Park et al. [49] indicated that consumers' willingness to participate in the events that a firm organizes has a positive effect on their brand loyalty and repurchasing intention of the firm's market offerings. We thus develop the following hypotheses.

Hypothesis 1. Reciprocity will significantly increase a consumer's intention to participate in the philanthropic activities of the company.

Hypothesis 2. Reciprocity will significantly increase a consumer's intention to purchase the company's products.

Hypothesis 3. A consumer's intention to participate in the philanthropic activities of the company will significantly increase his/her purchasing intention of the company's products.

Next, we look into the moderating effects of two cognitive judgments affecting the relationship between reciprocity and patronage intentions: (1) the licensing effect, specifically vicarious licensing; and (2) the fit judgment between a firm's philanthropic activities and the firm's expertise.

\subsection{Licensing Effect}

The licensing effect refers to a subconscious phenomenon whereby a behavior occurring before a certain choice is made serves as the justification for the decision afterward [50]. For example, consumers who had performed volunteer work immediately beforehand had a strong tendency to prefer and choose hedonic products as a reward for the volunteer work that they had just performed [51]. This is because the consumer views the altruistic behavior carried out before their product choice as a justification to pursue pleasure [52].

This justification mechanism does not always need to involve specific and tangible altruistic behavior prior to an irresponsible choice. Even just the expression of an intention to act virtuously 
can serve as a license for the subsequent behavior of not acting so virtuously and responsibly [53]. Licensing effects can also be triggered by observation and/or inference, i.e., vicarious licensing. For example, Kouchaki [54] showed that observing or learning about someone's ethical activity can make others behave more or less ethically as an outcome. The empirical result of his experiment supported the effects of vicarious licensing, such that if a respondent knew that others had already behaved morally on their behalf, the respondent tended to behave less morally and more indulgently. We thus predict that this vicarious licensing (i.e., the perception that the company already contributed to the society through philanthropic activities on their behalf) would weaken the effect of reciprocity on the behavioral intention to participate in the company's philanthropic activities, as well as their willingness to purchase the company's market offering.

Hypothesis 4. Vicarious licensing will significantly weaken the effect of reciprocity on the intention to participate in the company's philanthropic activities.

Hypothesis 5. Vicarious licensing will significantly weaken the effect of reciprocity on the intention to purchase the company's products.

\subsection{The Fit between the Philanthropically Activities and Company's Expertise}

Another variable that could moderate the role of $\mathrm{CP}$ in shaping a consumer's behavioral intentions is the evaluation of a fit between the characteristics of the philanthropic activities that a firm engages in and the firm's core expertise. A greater fit between the two would increase the accessibility and credibility of information about the firm's CP activities [55] and lead to a positive congruence judgment $[56,57]$, which in turn affects the consumer's perception as to whether a firm's chosen activities are appropriate and genuine. Past studies have supported that this judgment of fit is an important consideration that consumers look for when evaluating a firm's CSR activities. Drumwright [58] and Myers et al. [59] showed that consumer attitudes toward CSR are significantly affected by the alignment between a company's CSR activities and its expertise. Bigné-Alcañiz et al. [60] also showed that the fit between the brand perception and types of causes that CSR support moderates the effect of CSR activities on enhancing consumer attitudes toward brands. This fit is further found to have a significant and positive effect on consumers' behavioral intentions $[60,61]$. We thus developed the following hypothesis.

Hypothesis 6. The fit between the company's philanthropic activities and its core expertise will significantly increase the effect of participation intention on purchasing intention.

Figure 1 depicts the hypothesized relationships discussed in this study.

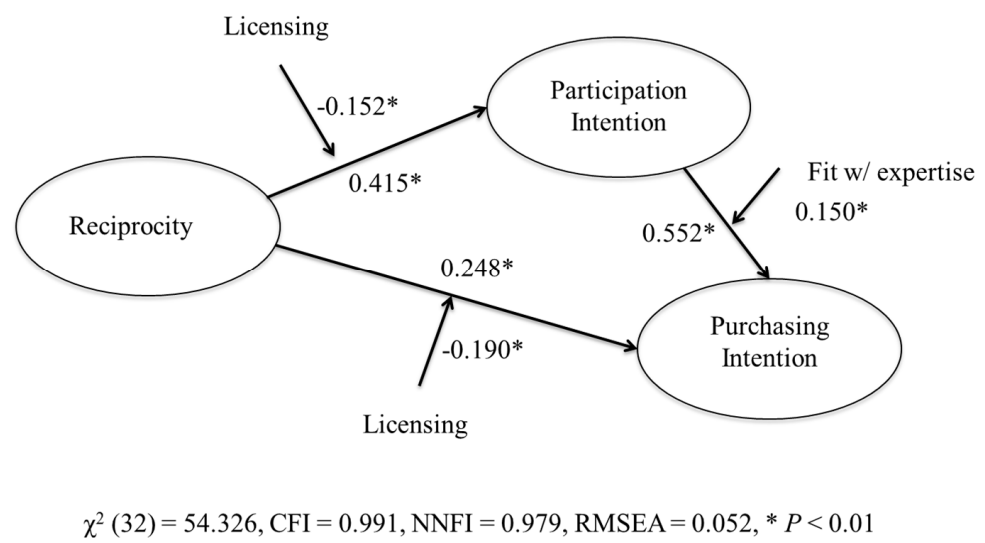

Figure 1. Conceptual Model and the Results from Structural Equation Modeling (SEM). 


\section{Methods}

The data for the study were collected in the context of the apparel industry. While much CSR literature concerning the apparel industry has discussed and emphasized the importance of sustainable production and sourcing that meets environmental and social responsibilities [62], in practice, philanthropic activities remain the most significant form of CSR that apparel companies employ [63].

Specifically, the data were collected via an online survey from the consumer panel of a marketing research firm in South Korea. Within a week of data collection, a total of 326 respondents filled out the survey. After excluding four responses due to incomplete data, we obtained a final sample size of 322. The final sample consisted of consumers in their $20 \mathrm{~s}(34.8 \%), 30 \mathrm{~s}(32.2 \%)$, and $40 \mathrm{~s}(32.6 \%)$. Approximately half of the respondents were female. The average monthly household income was around $\$ 4500$ and the average monthly expenditure on apparel products was $\$ 275$. A detailed profile of the final sample is presented in Table 1.

Table 1. Respondents' profile.

\begin{tabular}{|c|c|c|c|c|c|c|c|}
\hline & Variables & $\mathbf{N}$ & $\%$ & & Variables & $\mathbf{N}$ & $\%$ \\
\hline \multirow{3}{*}{ Gender } & Male & 162 & 50.3 & \multirow{3}{*}{ Age } & $20-29$ & 112 & 34.5 \\
\hline & \multirow{2}{*}{ Female } & \multirow{2}{*}{160} & \multirow{2}{*}{49.7} & & $30-39$ & 104 & 32.3 \\
\hline & & & & & $40-49$ & 106 & 32.9 \\
\hline \multirow{6}{*}{$\begin{array}{l}\text { Average monthly } \\
\text { expenditure on } \\
\text { apparel }\end{array}$} & Below 100 & 107 & 32.9 & \multirow{6}{*}{$\begin{array}{c}\text { Average } \\
\text { monthly income }\end{array}$} & Below 3000 & 92 & 28.6 \\
\hline & $101-200$ & 97 & 29.8 & & $3001-4000$ & 62 & 19.3 \\
\hline & $201-300$ & 58 & 18.0 & & $4001-5000$ & 61 & 18.9 \\
\hline & $301-400$ & 9 & 2.8 & & 5001-6000 & 32 & 9.9 \\
\hline & Above 400 & 51 & 15.8 & & Above 6000 & 64 & 19.9 \\
\hline & & & & & No response & 11 & 3.4 \\
\hline
\end{tabular}

\section{Instrument}

A questionnaire was developed to measure the constructs examined in this study. Respondents first read a script that described a particular philanthropic activity performed by an imaginary apparel company and were then asked to fill out the measurement items in the questionnaire. All measurement items used a seven-point Likert scale, ranging from 1 for "strongly disagree or highly unlikely" to 7 for "strongly agree or highly likely".

Six scripts were developed following the procedures descried below. We first collected specific cases of philanthropic activities performed by apparel companies in Korea by reviewing the companies' sustainability and annual reports. In so doing, we focused on the philanthropic activities organized and performed at the corporate level (i.e., the company as the giving entity), thus excluding cases where a company encouraged (e.g., through the matching mechanism) its employees to donate personal resources to the social causes that they supported. A total of 22 specific cases were identified, which was used as the basis for our script development. The review of these cases indicated that the philanthropic activities of apparel companies could be grouped into two distinct categories. One category is giving tangible assets (i.e., donation of money and company goods) and the other category is giving intangible assets (i.e., donation of a company's expertise, access to its distribution system, training opportunities, etc.).

Using actual cases, which we reviewed as guidelines, we created three different scripts for each type of giving, resulting in a total of six scripts. These scripts described an imaginary apparel company manufacturing and selling casual clothing for both men and women performing six different types of philanthropic activities. We used an imaginary company to avoid any biases caused by existing brands and corporate images, but the descriptions of the company followed the average characteristics of the existing brands that we examined. That is, this company was described as having about 500 employees with an annual revenue of approximately $\$ 600-\$ 800$ million; it manufactures about $40 \%$ of its garments 
from facilities that it owns and $60 \%$ of its garments are sourced from other suppliers; it retails its garments at company-owned specialty stores. Each scenario describes the company giving different forms of tangible assets by saying that the company: (1) donated 3\% of its profits in cash to support needy people in its community to buy food or grocery so that they do not skip meals or acquire utensils and ingredients to cook for themselves; (2) donated 3\% of its profits in cash to improve the residential environment of people in need in its community so that they can enjoy clean and healthy living spaces; or (3) donated 3\% of its profits in cash provide a need-based scholarship to those who cannot afford education in its community, so that they are able to attend colleges and take classes to improve their knowledge. Three other scripts described the company giving intangible assets by: (1) offering free laundry services to support people in need and those who cannot afford to wash their clothes frequently due to debilitating physical conditions and a lack of financial means; (2) teaching needy people sewing, ironing, pattern making, and other garment alteration skills in order to help them get a job and earn money; or (3) supporting local charity bazaar events or flea markets with a company's supplies such as hangers, mannequins, and mirrors in order to support the execution of these events.

These variations resulted in a total of six scripts. One of the scripts was presented to each respondent (Table 2). After collecting the data, we conducted a chi-square test to determine if the respondents assigned to each scenario differed in terms of gender, age, average monthly income, and average monthly spending. As reported in Table 3, the results indicate no significant differences between the groups of differing scenarios.

Table 2. The number of respondents in each condition.

\begin{tabular}{cccc}
\hline Type of Giving & Scenario 1 & Scenario 2 & Scenario 3 \\
\hline Money-giving & 54 & 56 & 52 \\
Expertise-giving & 53 & 52 & 55 \\
\hline
\end{tabular}

Table 3. Results of the $\chi^{2}$ analysis on each condition.

\begin{tabular}{cccc}
\hline Variable & $\boldsymbol{x}^{2}$ & Df & $p$ \\
\hline Gender & 321 & 5 & 0.997 \\
Age & 155.016 & 145 & 0.270 \\
Average monthly income & 206.474 & 215 & 0.650 \\
Average monthly expenditure on apparel & 91.822 & 105 & 0.817 \\
\hline
\end{tabular}

The measurement items were derived from the previous studies and modified to reflect the context of the current study. Specifically, the measurement items for reciprocity were adapted from Chan and Li [64], Chesters and Lawrence [65], and Morales [46]. The items for the licensing effect are from Khan and Dhar [50] and Kouchaki [54], and those of the fit evaluation are from Becker-Olsen et al. [66]. The items of participation intention are based on items by Folse et al. [67], and those of the purchase intention were from Fournier [68] and Keller [69]. The final items used in the study are presented in Table 4. 
Table 4. Results of the confirmatory factor analysis.

\begin{tabular}{|c|c|c|c|c|c|}
\hline Variables & Scales & Factor Loading & AVE & CR & Cronbach's $\alpha$ \\
\hline \multirow{3}{*}{ Reciprocity } & $\begin{array}{l}\text { I feel I owe the company for its philanthropic activities as a local resident } \\
\text { who might be a beneficiary. }\end{array}$ & 0.860 & \multirow{3}{*}{0.715} & \multirow{3}{*}{0.883} & \multirow{3}{*}{0.875} \\
\hline & $\begin{array}{l}\text { I would like to return the company's philanthropic activities in full as } \\
\text { a local resident who might be a beneficiary. }\end{array}$ & 0.895 & & & \\
\hline & $\begin{array}{l}\text { I appreciate the company's philanthropic responsibility activities as } \\
\text { a local resident who might be a beneficiary. }\end{array}$ & 0.7784 & & & \\
\hline \multirow{3}{*}{ Participation Intention } & $\begin{array}{l}\text { I would like to participate in the company's philanthropic activities } \\
\text { mentioned above. }\end{array}$ & 0.782 & \multirow{3}{*}{0.772} & \multirow{3}{*}{0.910} & \multirow{3}{*}{0.893} \\
\hline & $\begin{array}{l}\text { I will support the company's philanthropic activities by way of } \\
\text { purchasing products or services where a portion of profits goes to } \\
\text { support these activities. }\end{array}$ & 0.887 & & & \\
\hline & $\begin{array}{l}\text { I would like to contribute to realize common good through my } \\
\text { participation in the company's philanthropic activities mentioned above. }\end{array}$ & 0.908 & & & \\
\hline \multirow{4}{*}{ Purchase Intention } & $\begin{array}{l}\text { I will preferentially consider buying the products or } \\
\text { service of the company. }\end{array}$ & 0.855 & \multirow{4}{*}{0.804} & \multirow{4}{*}{0.943} & \multirow{4}{*}{0.945} \\
\hline & I will recommend buying the products or service of the company. & 0.897 & & & \\
\hline & I feel like buying the products or service of the company. & 0.918 & & & \\
\hline & I will definitely consider buying the products or service of the company. & 0.916 & & & \\
\hline \multirow{2}{*}{ Vicarious Licensing } & $\begin{array}{l}\text { After knowing the company's philanthropic activities mentioned above, } \\
\text { I feel that the company does good thing for the society on behalf of me. }\end{array}$ & 0.802 & \multirow{2}{*}{0.659} & \multirow{2}{*}{0.707} & \multirow{2}{*}{0.700} \\
\hline & $\begin{array}{l}\text { I feel that the company's philanthropic activities contributed } \\
\text { significantly to improving the community on my behalf. }\end{array}$ & 0.674 & & & \\
\hline \multirow{4}{*}{ Strategic Fit } & $\begin{array}{l}\text { The philanthropic responsibility activities fit well with the apparel } \\
\text { company's core expertise. }\end{array}$ & 0.909 & \multirow{4}{*}{0.797} & \multirow{4}{*}{0.977} & \multirow{4}{*}{0.939} \\
\hline & $\begin{array}{l}\text { The philanthropic responsibility activities similar with the apparel } \\
\text { company's core expertise. }\end{array}$ & 0.919 & & & \\
\hline & $\begin{array}{l}\text { The philanthropic responsibility activities are consistent with the apparel } \\
\text { company's core expertise. }\end{array}$ & 0.906 & & & \\
\hline & $\begin{array}{l}\text { The philanthropic responsibility activities and apparel company's core } \\
\text { expertise are complementary. }\end{array}$ & 0.835 & & & \\
\hline
\end{tabular}




\section{Data Analysis}

\subsection{Measurement Test}

First, a confirmatory factor analysis (CFA) with the maximum likelihood method [70] was used to evaluate the measurement model in terms of reliability, convergent validity, and discriminant validity. The results of the confirmatory analysis showed a good fit $\left(\chi^{2}=113.977, \mathrm{df}=48, p=0.000, \mathrm{GFI}=0.943\right.$, $\mathrm{AGFI}=0.907, \mathrm{CFI}=0.979, \mathrm{RMR}=0.057$ and RMSEA $=0.061)$. Convergent validity was evaluated by checking the significance of the $t$-values for each path coefficient of the CFA model [71]. As shown in Table 1, the $t$-values for all path coefficients were significant. All of the constructs' estimated average variances extracted (AVE) were over 0.50 , and the composite reliabilities were over 0.70 , which confirmed the convergent validity. We also found that the AVE estimates of all the constructs were larger than the corresponding squared inter-construct correlation estimates [71]. We thus concluded that our measurement model also satisfied the discriminant validity.

\subsection{Model Test}

Structural equation modeling (SEM) with the maximum likelihood method [72] was used to examine the hypothesized relationships depicted in Figure 1. The model fit was tested using the comparative fit index, non-normed fit index, and room mean square error of approximation (RMSEA) [73]. The results indicate that our structural model has a good fit to the data $\left(\chi^{2}(32)=54.326\right.$, $\mathrm{CFI}=0.991, \mathrm{NNFI}=0.979$, RMSEA $=0.052$ ).

First, we found that reciprocity had a significant and positive effect on both participation intention ( $\beta=0.415, p<0.05)$ and purchasing intention $(\beta=0.248, p<0.05)$. We therefore support Hyphothesis 1 and Hyphothesis 2. We also found that participation intention had a significant and positive effect on purchasing intention $(\beta=0.552, p<0.05)$, thus supporting Hyphothesis 3 . As for the moderating roles of vicarious licensing, it was found to significantly reduce the effect of reciprocity on both participation intention $(\beta=-0.152, p<0.005)$ and purchasing intention $(\beta=-0.190, p<0.05)$. We thus support Hyphothesis 4 and Hyphothesis 5. The result also indicated a significant and positive role of the fit moderating the effect of participation intention on purchasing intention $(\beta=0.150, p<0.05)$, thus supporting Hyphothesis 6. The detailed results are presented in Figure 1.

Next, we conducted a stepwise regression analysis in order to confirm the main hypotheses and the mediating effect of participation intention [74-76], and the results are presented in Table 5. As shown in Table 4, the addition of participation intention as a mediating variable significantly increases the adjusted $\mathrm{R}^{2}$ of the model. Specifically in step 3 , the path from participation intention to purchasing intention is significantly positive $(\beta=0.427)$ and reduces the direct effect of reciprocity on purchasing intention from $\beta=0.655$ to $\beta=0.187$ (both are significant at $p<0.000$ ), thus supporting the mediating effect of participation intention as depicted in our model.

Table 5. The results of the three-step regression analysis.

\begin{tabular}{ccccc}
\hline Step & Path & Adjusted R $^{2}$ & $\boldsymbol{\beta}$ & $\boldsymbol{p}$ \\
\hline Step 1 & Reciprocity $\rightarrow$ Purchasing Intention & 0.427 & 0.655 & 0.000 \\
Step 2 & Reciprocity $\rightarrow$ Participation Intention & 0.484 & 0.697 & 0.000 \\
Step 3 & Participation Intention $\rightarrow$ Purchasing Intention & 0.427 & 0.655 & 0.000 \\
Step 4 & Reciprocity $\rightarrow$ Purchasing Intention & 0.659 & 0.187 & 0.000 \\
& Participation Intention $\rightarrow$ Purchasing Intention & & 0.672 & 0.000 \\
\hline
\end{tabular}

Next, in order to validate the moderating roles of vicarious licensing and strategic fit, we employed a multiple moderated regression [74-76] and the results are presented in Tables 6-8. As for vicarious licensing as a variable moderating the effect of reciprocity on participation intention, model 1 examines only the direct effect of reciprocity on participation intention, model 2 includes reciprocity and vicarious licensing as separate independent variables, and model 3 examines the effect of reciprocity and the 
interaction effect of vicarious licensing on participation intention. As can be seen in Table 6, the change in the adjusted $\mathrm{R}^{2}$ of Model 3 is significantly greater than that of Models 1 and 2, thus confirming the moderating role of vicarious licensing. We followed the same steps to test the moderating roles of vicarious licensing on purchasing intention (Table 7) and strategic fit (Table 8). As shown in Tables 7 and 8 , the changes in the adjusted $R^{2}$ of model 3 are significant, thus supporting the role of vicarious licensing and strategic fit as illustrated in our model.

Table 6. The results of testing the moderating effect of licensing perception.

\begin{tabular}{cccc}
\hline Model & Adjusted $\mathbf{R}^{2}$ & F Change & Significance Level of F Change \\
\hline Model 1 $^{\mathrm{a}}$ & 0.484 & 247.082 & 0.000 \\
Model 2 $^{\mathrm{b}}$ & 0.579 & 59.578 & 0.000 \\
Model 3 $^{\mathrm{c}}$ & 0.596 & 12.222 & 0.001 \\
\hline
\end{tabular}

a reciprocity $\rightarrow$ participation intention; ${ }^{b}$ reciprocity and licensing perception $\rightarrow$ participation intention; ${ }^{\mathrm{c}}$ reciprocity, licensing effect, and reciprocity $\times$ licensing perception $\rightarrow$ participation intention.

Table 7. The results of testing the moderating effect of licensing perception.

\begin{tabular}{cccc}
\hline Model & Adjusted $\mathbf{R}^{2}$ & F Change & Significance Level of F Change \\
\hline Model 1 $^{\mathrm{a}}$ & 0.427 & 196.447 & 0.000 \\
Model 2 $^{\mathrm{b}}$ & 0.489 & 32.679 & 0.000 \\
Model 3 $^{\mathrm{c}}$ & 0.507 & 10.122 & 0.002 \\
\hline
\end{tabular}

a reciprocity $\rightarrow$ purchasing intention; ${ }^{b}$ reciprocity and licensing perception $\rightarrow$ purchasing intention; ${ }^{c}$ reciprocity, licensing effect, and reciprocity $\times$ licensing perception $\rightarrow$ purchasing intention.

Table 8. The results of testing the moderating effect of strategic fit.

\begin{tabular}{cccc}
\hline Model & Adjusted $\mathbf{R}^{2}$ & F Change & Significance Level of F Change \\
\hline Model 1 $^{\mathrm{a}}$ & 0.642 & 470.457 & 0.000 \\
Model 2 $^{\mathrm{b}}$ & 0.651 & 7.785 & 0.006 \\
Model 3 $^{\mathrm{c}}$ & 0.655 & 4.226 & 0.041 \\
\hline
\end{tabular}

${ }^{a}$ participation intention $\rightarrow$ purchasing intention; ${ }^{b}$ participation intention and strategic fit $\rightarrow$ purchasing intention; $c$ participation intention, strategic fit, and participation intention $\times$ strategic fit $\rightarrow$ purchasing intention.

\subsection{Additional Invariance Test}

Although it was not hypothesized given the lack of previous studies indicating how different forms of philanthropic activities would affect the relationships depicted in our model, we explored whether the proposed model would differ between two categories of scenarios (i.e., giving tangible assets vs. intangible assets). We separated the data collected into the scenarios where tangible assets were given and the scenarios where intangible assets were given, and then employed the invariance test to examine how the relationships depicted in our model would differ in terms of the two situations. Specifically, the baseline model with all path parameters in both groups set free (Model 1) was compared with the restricted model with a particular path fixed to be equal between two groups (Model 2). We examined the chi-square difference between Model 1 and Model 2 and examined the modification indices to determine specific paths whose estimates are significantly different between donating tangible assets and donating intangible assets. The results are presented in Table 9.

As indicated in Table 9, the results from the invariance test indicated that the path from reciprocity to participation intention and the path from reciprocity to purchasing intention were significantly different for each group. Specifically, the effect of reciprocity on participation intention was significantly higher for giving intangible assets than that for giving tangible assets $\left(\beta_{\text {tangible-giving }}=0.137 \mathrm{vs}\right.$. $\left.\beta_{\text {intangible-giving }}=0.640 ; \chi^{2} \mathrm{~d}(1)=4.186, p<0.05\right)$. Likewise, the effect of reciprocity on purchasing intention was significantly higher for giving intangible assets than that for giving tangible assets 
$\left(\beta_{\text {tangible-giving }}=0.137\right.$ vs. $\left.\beta_{\text {intangible-giving }}=0.420 ; \chi^{2} \mathrm{~d}(1)=2.375, p<0.05\right)$. We also found that the moderating effect of fit with expertise was more pronounced for the intangible-giving condition than the tangible-giving condition ( $\beta_{\text {tangible-giving }}=0.140$ vs. $\beta_{\text {intangible-giving }}=0.262 ; \chi^{2} \mathrm{~d}(1)=6.78, p<0.05$ ). We did not find any significant differences for the effect of participation intention on purchasing intention, nor for the moderating role of vicarious learning between the two groups.

Table 9. The results of the SEM model and invariance test between a tangible vs. intangible gift.

\begin{tabular}{cccccc}
\hline \multirow{2}{*}{ Path } & \multicolumn{2}{c}{ Tangible Gift } & \multicolumn{2}{c}{ Intangible Gift } & \multirow{2}{*}{ C.R. } \\
\cline { 2 - 5 } & $\mathbf{B}$ & $\boldsymbol{p}$ & $\boldsymbol{\beta}$ & $\boldsymbol{p}$ & \\
\hline Reciprocity $\rightarrow$ Participation Intention & 0.137 & 0.353 & 0.640 & 0.000 & $4.186^{*}$ \\
Reciprocity $\rightarrow$ Purchasing Intention & 0.137 & 0.063 & 0.420 & 0.000 & $2.375^{*}$ \\
Participation Intention $\rightarrow$ Purchasing Intention & 0.682 & 0.014 & 0.354 & 0.003 & 0.228 \\
Licensing * Reciprocity $\rightarrow$ Participation Intention & -0.208 & 0.000 & -0.187 & 0.000 & -1.408 \\
Licensing * Reciprocity $\rightarrow$ Purchasing Intention & -0.120 & 0.101 & -0.268 & 0.000 & -0.342 \\
Participation * Fit $\rightarrow$ Purchasing Intention & -0.140 & 0.002 & 0.262 & 0.000 & $-1.987^{*}$ \\
\hline
\end{tabular}

\section{Discussion}

This study has investigated the perceptual and behavioral mechanism regarding the effect of $\mathrm{CP}$ on consumer behavioral intentions. Specifically, we identified reciprocity as the key cognitive judgment determining both the consumers' willingness to participate in a firm's philanthropic activities and the willingness to purchase the firm's products. In addition, we have investigated how vicarious licensing and strategic fit would mitigate the relationship between reciprocity and patronage behavior. The proposed model was tested in the context of the philanthropic activities of apparel companies. The practical and theoretical implications of our study are as follows.

While CP has been generally regarded as one form of CSR, we follow the conceptualization that $\mathrm{CP}$ is distinct from CSR, thus warranting separate attention for examining its strategic role. The key tenet for this investigation is that the extent to which one feels indebted to return the kindness they received (i.e., reciprocity) is the mechanism of $\mathrm{CP}$ increasing consumer patronage behavior. The results indeed support the significant and positive effects of reciprocity on both participation intention (i.e., willingness to participate in philanthropic activities organized by the company) and purchasing intention (i.e., willingness to purchase the products/brands of the company that gave to their community). These results would mean that, although in principle philanthropy is conducted without a concern for positive remunerable returns for the firm, philanthropic activities could improve the firm's bottom line. The strategic role of $\mathrm{CP}$ is significantly enhanced when they are crafted and communicated in ways that increase in-group identification, thus evoking a high level of reciprocity. In addition, we examined whether participation intention would mediate the path from reciprocity to purchasing intention. The results indicate that the more one is willing to participate in a firm's philanthropic activities, the more that he/she is willing to purchase a product from the firm. This may be so, for the active involvement in a firm's philanthropic activities enhances one's perception that he/she is acting as an agent advocating philanthropic and business missions of the company. This could further enhance in-group identification with the firm $[47,77]$, thus resulting in a stronger willingness to support the firm's business by purchasing its market offerings.

Our study also identifies critical perceptual variables affecting the strengths of the relationship between reciprocity and patronage behavior. Specifically, we posit that vicarious licensing (i.e., consumers' perception that the firm conducted a good deed for their community on behalf of them) would weaken their obligation to give back, thus decreasing the impact of reciprocity on patronage intentions. Our results showed that vicarious licensing indeed reduces the effects of reciprocity not only on participation intention, but also on purchasing intention. This is in line with the results by Kouchaki [54] in that the licensing effect is not necessarily limited to one's own behavior 
and perceiving someone else performing ethical behavior on their behalf can make people behave less ethically. Our study is the first to confirm the significance of vicarious licensing in the context of $\mathrm{CP}$, underscoring the criticality of this perceptual framing in shaping behavioral decisions. The practical implications of this finding would be that emphasizing $\mathrm{CP}$ being carried out on its consumers' behalf would not be a desirable communication strategy, for it could significantly decrease the consumers' willingness to participate in the firm's philanthropic activities and to purchase its products.

As for the mediating role of strategic fit, we find that participation intention leading to purchasing intention increases when consumers perceive a greater fit between a firm's expertise and its philanthropic activities. That is, although $\mathrm{CP}$ activities are not directly connected to core businesses, consumers still evaluate the link between $\mathrm{CP}$ and a firm's characteristics, particularly in terms of what they see that the firm is good at performing (i.e., perceived expertise). A similar argument was made by Porter and Kramer [78] that CP conducted in a way that aligns with the key business goals would benefit the firm in terms of enhancing the bottom line, reputation, and relationship building. It is important to note, however, that the fit discussed in Porter and Kramer [78] is the fit between the goal (i.e., desirable objectives to accomplish via the current and future operations which set by the company) and $\mathrm{CP}$ activities. The strategic fit in our study takes a more consumer-centric perspective in that it is employed to capture the judgment made by consumers and the evaluation based on the firm's past and current engagement and performances, rather than the future. Furthermore, our study tests and demonstrates that strategic fit is particularly critical in strengthening the effect of participation intention increasing purchasing intention. The practical implication of this finding would be that to maximize the positive strategic outcome that a firm can obtain through its philanthropy, the firm should first investigate what kinds of expertise it is perceived to possess by consumers, which in turn should be used as an evaluation criterion when deciding which philanthropy activity it will support.

Despite the fact that firms donate not only tangible assets but also intangible assets, not much attention has been given to understanding whether and how a consumer would evaluate these two forms of giving differently. We further contribute to the current $\mathrm{CP}$ literature by exploring whether the strategic role of $\mathrm{CP}$ affecting consumer patronage would differ between different kinds of giving conditions, particularly between donating tangible assets and intangible assets. That is, the feeling of indebtedness leading to consumer patronage behaviors are stronger when a firm's philanthropic activities are shaped in a way to empower the community by providing education, sharing expertise, and allowing access to its infrastructure rather than giving money and other tangible goods to the community. In addition, we found that the moderating role of fit strengthened the effect from the participation intention to the purchasing intention when giving intangible assets compared to when giving tangible assets. This would imply that a firm should pay greater attention to the fit between a firm's perceived expertise and the kinds of philanthropic activities that it decides to engage in, particularly when planning for $\mathrm{CP}$ involving intangible assets.

The results of this study should be interpreted with the specific context in mind since the data of the current study were collected from a particular industry. A future study may extend our framework to other types of products and services and examine whether the findings reported in our study would also hold for other industry contexts. Additionally, the data were collected using an online survey. We recognize that some characteristics of the respondents might have been different had we collected the data using a traditional mailing survey, such as a computer or Internet acceptance and utilization. While we do not believe that these characteristics would have affected our constructs critically, a future study may test the validity of our model using different data collection methods. In addition, we note that the social identity induced by our scripts is related to a geographically confined community. However, a social community can be formed beyond geographic boundaries, such as communities in a social network. A future study may examine whether and how the relationships depicted in our model would be affected if the data were collected involving communities not restricted by geographic identities. Lastly, the study was conducted in Korea, which has more of a national propensity towards collectivism than that of western countries such as America or England. A higher 
level of collectivism might have resulted in a greater level of reciprocity from $\mathrm{CP}$ designated toward one's own community. In a future study, it would be interesting to compare the relationships depicted in our study in a cross-cultural context to better understand how cross-cultural differences would come into play when determining the effectiveness of philanthropic activities on consumer patronage toward firms.

Acknowledgments: This work was supported by the National Research Foundation of Korea Grant funded by the Korean Government (NRF-2016S1A2A2912526).

Author Contributions: Erin Cho, Jihyun Lee and Yuri Lee conceived and designed the experiments; Jihyun Lee and Yuri Lee performed the experiments; Jihyun Lee analyzed the data; Erin Cho, Jihyun Lee and Yuri Lee contributed reagents/materials/analysis tools; Erin Cho wrote the paper.

Conflicts of Interest: The authors declare no conflict of interest.

\section{References}

1. Carroll, A.B. The pyramid of corporate social responsibility: Toward the Moral Management of Organizational Stakeholders. Bus. Horiz. 1991, 34, 39-48. [CrossRef]

2. Norwalk, C.T. Exposure Draft: Accounting for Stock-Based Compensation. FASB 2002, 123. Available online: http:/ / www.fasb.org/news/nr100402.shtml (accessed on 17 April 2017).

3. Burnell, P.; Randall, V.; Rakner, L. Politics in the Developing World, 4th ed.; Oxford University Press: Oxford, UK, 2014; pp. 286-288.

4. Giving USA Foundation. Giving USA 2016. Available online: http://cfnwmo.org/wp-content/uploads/ 2016/07/Giving-USA-2016.pdf (accessed on 10 May 2017).

5. Lin, L. Corporate Social Responsibility in China: Window Dressing or Structural Change? Berkeley J. Int. Law 2010, 28, 64-100.

6. McWilliams, A.; Siegel, D. Corporate social responsibility: A theory of the firm perspective. Acad. Manag. Rev. 2001, 26, 117-127.

7. Carroll, A.B.; Shabana, K.M. The business case for corporate social responsibility: A review of concepts, research and practice. Int. J. Manag. Rev. 2010, 12, 85-105. [CrossRef]

8. Pivato, S.; Misani, N.; Tencati, A. The impact of corporate social responsibility on consumer trust: The case of organic food. Bus. Ethics 2008, 17, 3-12. [CrossRef]

9. Smith, T. Institutional and social investors find common ground. J. Invest. 2005, 14, 57-65. [CrossRef]

10. Mintzberg, H. The case for corporate social responsibility. J. Bus. Strategy 1983, 4, 3-15. [CrossRef]

11. Valor, C. Can consumers buy responsibly? Analysis and solutions for market failures. J. Consum. Policy 2008, 31, 315-326. [CrossRef]

12. Han Economic Research Institute. Chinese companies become interested in CSR. 2010. Available online: http:/ /heri.kr/2545 (accessed on 26 July 2016). (In Korean)

13. Schwartz, M.S.; Carroll, A.B. Corporate social responsibility: A three-domain approach. Bus. Ethics Q. 2003, 13, 503-530. [CrossRef]

14. Anheier, H.K.; Leat, D. Creative Philanthropy: Toward a New Philanthropy for the Twenty-First Century; Routledge: New York, NY, USA, 2006.

15. Von Schnurbein, G.; von Schnurbein, G.; Seele, P.; Seele, P.; Lock, I.; Lock, I. Exclusive corporate philanthropy: Rethinking the nexus of CSR and corporate philanthropy. Soc. Responsib. J. 2016, 12, 280-294. [CrossRef]

16. Leisinger, K.M. Corporate philanthropy: The 'top of the pyramid'. Bus. Soc. Rev. 2007, 112, 315-342. [CrossRef]

17. Matten, D.; Moon, J. "Implicit" and "explicit" CSR: A conceptual framework for a comparative understanding of corporate social responsibility. Acad. Manag. Rev. 2008, 33, 404-424. [CrossRef]

18. Godfrey, P.C. The Relationship between Corporate Philanthropy and Shareholder Wealth: A Risk Management Perspective. Acad. Manag. Rev. 2005, 30, 777-798. [CrossRef]

19. Burlingame, D. Corporate giving. Int. J. Nonprofit Volunt. Sect. Mark. 2011, 6, 4-5. [CrossRef]

20. Husted, B.W.; De Jesus Salazar, J. Taking Friedman Seriously: Maximizing Profits and Social Performance. J. Manag. Stud. 2006, 43, 75-91. [CrossRef]

21. Brønn, P.S.; Vrioni, A.B. Corporate social responsibility and cause-related marketing: An overview. Int. J. Advert. 2001, 20, 207-222. [CrossRef] 
22. Saiia, D.H.; Carroll, A.B.; Buchholtz, A.K. Philanthropy as strategy: When corporate charity 'begins at home'. Bus. Soc. 2003, 42, 169-201. [CrossRef]

23. Schuler, D.A.; Cording, M.A. Corporate social performance-corporate financial performance behavioral model for consumers. Acad. Manag. Rev. 2006, 31, 540-558. [CrossRef]

24. Haslam, S.A. Psychology in Organizations: The Social Identity Approach; Sage Ltd.: London, UK, 2001; pp. $213-215$.

25. Tajfel, H. Differentiation between Social Groups; Academic Press: London, UK, 1978.

26. Tajfel, H. Individuals and groups in social psychology. Br. J. Soc. Clin. Psychol. 1979, 18, 183-190. [CrossRef]

27. Turner, J.C.; Hogg, M.A.; Oakes, P.J.; Reicher, S.D.; Wetherell, M.S. Rediscovering the Social Group: A Self-Categorization Theory; Basil Blackwell: New York, NY, USA, 1987; p. 239.

28. Hogg, M.A.; Abrams, D. Social motivation, self-esteem and social identity. Soc. Identity Theory 1990, $28,47$.

29. Tajfel, H. Social identity and intergroup behaviour. Information 1974, 13, 65-93. [CrossRef]

30. Weiss, D.; Lang, F.R. "They" are old but "I" feel younger: Age-group dissociation as a self-protective strategy in old age. Psychol. Aging 2012, 27, 153-163. [CrossRef] [PubMed]

31. Sindic, D.; Condor, S. Social Identity Theory and Self-Categorisation Theory. In The Palgrave Handbook of Global Political Psychology; Palgrave Macmillan: London, UK, 2014; pp. 39-54.

32. Tajfel, H.; Turner, J.C. An integrative theory of intergroup conflict. Soc. Psychol. Intergroup Relat. 1979, $33,74$.

33. Turner, J.C.; Tajfel, H. The social identity theory of intergroup behavior. Psychol. Intergroup Relat. 1986, 7-24.

34. Hogg, M.A.; Terry, D.I. Social identity and self-categorization processes in organizational contexts. Acad. Manag. Rev. 2000, 25, 121-140.

35. Schlenker, B.R. Attitudes as actions: Social identity theory and consumer research. Adv. Consum. Res. 1978, 5, 352-359.

36. Collier, J.; Esteban, R. Corporate social responsibility and employee commitment. Bus. Ethics 2007, 16, 19-33. [CrossRef]

37. Marin, L.; Ruiz, S.; Rubio, A. The role of identity salience in the effects of corporate social responsibility on consumer behavior. J. Bus. Ethics 2009, 84, 65-78. [CrossRef]

38. Peloza, J.; Shang, J. How can corporate social responsibility activities create value for stakeholders? A systematic review. J. Acad. Mark. Sci. 2011, 39, 117-135. [CrossRef]

39. Regan, D.T. Effects of a favor and liking on compliance. J. Exp. Soc. Psychol. 1971, 7, 627-639. [CrossRef]

40. Gouldner, A.W. The norm of reciprocity: A preliminary statement. Am. Soc. Rev. 1960, 25, 161-178. [CrossRef]

41. Falka, A.; Fischbacherb, U. A theory of reciprocity. Games Econ. Behav. 2006, 54, 293-315. [CrossRef]

42. Arrow, K.J. Gifts and Exchanges. Philos. Public Aff. 1972, 1, 343-362.

43. Park, J.; Ryu, G. The effects of corporate ability and social responsibility associations on customer attitudes: The mediating role of credibility- and benevolence-based Trust. J. Korean Mark. Assoc. 2012, 27, 1-25.

44. Palmatier, R.W.; Jarvis, C.; Bechkoff, J.; Frank, R.K. The role of customer gratitude in relationship marketing. J. Mark. 2009, 73, 1-18. [CrossRef]

45. Dawson, S. Four motivations for charitable giving: Implications for marketing strategy to attract monetary donations for medical research. J. Health Care Mark. 1988, 8, 31-37. [PubMed]

46. Morales, A.C. Giving Firms an "E" for Effort: Consumer Responses to High-Effort Firms. J. Consum. Res. 2005, 31, 806-812. [CrossRef]

47. Bettencourt, L.A. Customer voluntary performance: Customers as partners in service delivery. J. Retail. 1997, 73, 383-406. [CrossRef]

48. Rosenbaum, M.S.; Massiah, C.A. When customers receive support from other customers: Exploring the influence of intercustomer social support on customer voluntary performance. J. Serv. Res. 2007, 9, 257-270. [CrossRef]

49. Park, J.; Lee, H.; Kim, C. Corporate social responsibilities, consumer trust and corporate reputation: South Korean consumers' perspectives. J. Bus. Res. 2014, 67, 295-302. [CrossRef]

50. Khan, U.; Dhar, R. Licensing Effect in Consumer Choice. J. Mark. Res. 2006, 43, 259-266. [CrossRef]

51. Strahilevitz, M.; Myers, J.G. Donations to Charity as Purchase Incentives: How well they work may depend on what you are trying to sell. J. Consum. Res. 1998, 24, 434-446. [CrossRef]

52. Park, J.; Kim, Y. Agent licensing effect of cause-related activity on product choice justification. J. Mark. Assoc. 2012, 28, 93-114.

53. Chaplin, L.N.; John, D.R. The development of self-brand connections in children and adolescents. J. Consum. Res. 2005, 32, 119-129. [CrossRef] 
54. Kouchaki, M. Vicarious moral licensing: The influence of others' past moral actions on moral behavior. J. Personal. Soc. Psychol. 2011, 101, 702-715. [CrossRef] [PubMed]

55. Feldman, J.M.; Lynch, J.G. Self-generated validity and other effects of measurement on belief, attitude, intention, and behavior. J. Appl. Psychol. 1988, 73, 421-435. [CrossRef]

56. Bhattacharya, C.B.; Sen, S. Consumer-company identification: A framework for understanding consumers' relationships with companies. J. Mark. 2003, 67, 76-88. [CrossRef]

57. Larson, J. If you're not committed, don't bother. Am. Demogr. 1994, 16, 16-18.

58. Drumwright, M.E. Company advertising with a social dimension: The role of noneconomic criteria. J. Mark. 1996, 60, 71-87. [CrossRef]

59. Myers, B.; Kwon, W.; Forsythe, S. Creating Effective Cause-Related Marketing Campaigns: The Role of Cause-Brand Fit, Campaign News Source, and Perceived Motivations. Cloth. Text. Res. J. 2012, 30, 167-182. [CrossRef]

60. Bigné-Alcañiza, E.; Currás-Péreza, R.; Ruiz-Maféa, C.; Sanz-Blasa, S. Cause-related marketing influence on consumer responses: The moderating effect of cause-brand fit. J. Mark. Commun. 2012, 18, 265-283. [CrossRef]

61. Gupta, M.; Hodges, N. Corporate social responsibility in the apparel industry: An exploration of Indian consumers' perceptions and expectations. J. Fash. Mark. Manag. 2012, 16, 216-233. [CrossRef]

62. Cooke, F.L.; He, Q. Corporate social responsibility and HRM in China: A study of textile and apparel enterprises. Asia Pac. Bus. Rev. 2010, 16, 355-376. [CrossRef]

63. Arrigo, E. Corporate responsibility management in fast fashion companies: The Gap Inc. case. J. Fash. Mark. Manag. 2013, 17, 175-189. [CrossRef]

64. Chan, K.; Li, S. Understanding consumer-to-consumer interactions in virtual communities: The salience of reciprocity. J. Bus. Res. 2010, 63, 1033-1040. [CrossRef]

65. Chesters, C.; Lawrence, S. The Business of Doing Good: An Australasian Perspective on Corporate Philanthropy. J. Corp. Citizensh. 2008, 31, 89-104. [CrossRef]

66. Becker-Olsen, K.L.; Cudmore, B.A.; Hill, R.P. The impact of perceived corporate social responsibility on consumer behavior. J. Bus. Res. 2006, 59, 46-53. [CrossRef]

67. Folse, J.; Niedrich, R.; Grau, S. Cause Related Marketing: The Effects of Purchase Quantity and Firm Donation Amount on Consumer Inferences and Participation Intentions. J. Retail. 2010, 86, 295-309. [CrossRef]

68. Fournier, S. Consumers and Their Brands: Developing Relationship Theory in Consumer Research. J. Consum. Res. 1998, 24, 343-373. [CrossRef]

69. Keller, K.L. Handbook of Marketing. In Branding and Brand Equity; Weitz, B., Wensley, R., Eds.; Sage Publications: London, UK, 2002; p. 151.

70. Jöreskog, K.G.; Sörbom, D. LISREL 8.80 for Windows [Computer Software]; Scientific Software International: Lincolnwood, IL, USA, 2006.

71. Fornell, C.; Larcker, D.F. Evaluating Structural Equation Models with Unobservable Variables and Measurement Error: Algebra and Statistics. J. Mark. Res. 1981, 18, 382-388. [CrossRef]

72. Harris, J.; Stocker, H. Handbook of Mathematics and Computational Science; Springer: New York, NY, USA, $1998 ;$ p. 824.

73. Hair, J.F.; Black, W.C.; Babin, B.J.; Anderson, R.E.; Tatham, R.L. Multivariate Data Analysis, 6th ed.; Pearson Prentice Hall: Upper Saddle River, NJ, USA, 2006.

74. Aguinis, H.; Stone-Romero, E.F. Methodological artifacts in moderated multiple regression and their effects on statistical power. J. Appl. Psychol. 1997, 82, 192-206. [CrossRef]

75. Aiken, L.S.; West, S.G.; Reno, R.R. Multiple Regression: Testing and Interpreting Interactions; Sage: London, UK, 1991.

76. Baron, R.M.; Kenny, D.A. The moderator-mediator variable distinction in social psychological research: Conceptual, strategic, and statistical considerations. J. Personal. Soc. Psychol. 1986, 51, 1173-1182. [CrossRef]

77. Gruen, T.W. The outcome set of relationship marketing in consumer markets. Int. Bus. Rev. 1995, 4, 447-469. [CrossRef]

78. Porter, M.E.; Kramer, M.R. The Competitive Advantage of Corporate Philanthropy. Harv. Bus. Rev. 2002, 80, 56-68. [PubMed]

(C) 2017 by the authors. Licensee MDPI, Basel, Switzerland. This article is an open access article distributed under the terms and conditions of the Creative Commons Attribution (CC BY) license (http://creativecommons.org/licenses/by/4.0/). 